\title{
KEBERLANJUTAN USAHA PENANGKAPAN PURSE SEINE DI PEKALONGAN DITINJAU DARI ASPEK EFISIENSI USAHA
}

\author{
Purse Seiners Fishing Sustainability at Pekalongan : An Overview of Technical Efficiency Aspect
}

\author{
Dian Ayunita N.N. Dewi ${ }^{1)}$, B.A. Wibowo ${ }^{1)}$ dan Iqbal Ali Husni ${ }^{1)}$ \\ ${ }^{1)}$ Fakultas Perikanan dan Ilmu Kelautan, Universitas Diponegoro \\ Jl. Prof. Soedarto, SH, Tembalang, Semarang, Jawa Tengah - 50275, Telp/Fax. +6224 7474698 \\ dianayunita_nnd@live.undip.ac.id
}

\begin{abstract}
Abstrak
Tujuan dari penelitian ini adalah menghitung efiensi teknis usaha penangkapan purse seine di PPN Pekalongan secara stokastik dan deterministik dan menganalisis efisiensi teknis untuk mengetahui prospek keberlanjutan usaha penangkapan purse seine di PPN Pekalongan. Metode analisis menggunakan Stochastic Frontier Analysis (SFA) dan Deterministic Frontier Analysis (DFA). SFA dan DFA merupakan model parametrik yang digunakan untuk mengukur efisiensi teknis. Model 1: DFA dengan data cross-section akan diestimasi dengan COLS. Model 2: SFA dengan data cross-section akan diestimasi dengan ML (Maximum Likelihood). Model 3: SFA dengan data panel diestimasi dengan proses ML. Variabel independent yang digunakan pada penelitian ini adalah lama trip (fishing days atau $\mathrm{X}_{1}$ ), GRT (Gross Registered Tonnage atau $\mathrm{X}_{2}$ ) kapal, jumlah ABK (crew members atau $\mathrm{X}_{3}$ ) sebagai faktor determinan yang digunakan oleh penangkapan purse seine di lokasi penelitian. Dan variabel terikat (Y) adalah output yaitu produksi tangkapan per tahun dari tahun 2015-2017. Fokus penelitian pada kapal purse seine berukuran 60-90 GT. Hasil dari penelitian ini adalah efisiensi teknis dari kedua kelompok kapal menunjukkan nilai inefisiensi dalam penggunaan ketiga variabel input. Hal ini diperkuat dengan hasil nilai korelasi (R) pada metode Deterministik Frontier dan Stokastik Frontier dengan data cross section serta panel data yang rendah $\left(0,39\right.$ dan 0,311). Variabel $\mathrm{X}_{1}$ (lama trip) memiliki hubungan negatif dengan variabel $\mathrm{Y}$ (produksi) sedangkan $\mathrm{X}_{2}$ dan $\mathrm{X}_{3}$ memiliki hubungan positif terhadap $\mathrm{Y}$. Pada armada penangkapan purse seine ukuran 60-90 GT, ketiga variabel input tidak mempunyai pengaruh yang signifikan terhadap perubahan jumlah produksi penangkapan.
\end{abstract}

Kata Kunci : Purse Seine; Efisiensi Teknis; PPN Pekalongan

\section{PENDAHULUAN}

Armada penangkapan merupakan salah satu faktor dominan yang menentukan daya jelajah kegiatan eksplorasi perikanan. Dengan armada penangkapan yang berkapasitas dan berkekuatan besar dapat mendukung kegiatan penangkapan di area yang semakin luas. Indonesia sebagai salah satu negara maritim membutuhkan armada penangkapan yang handal untuk dapat melakukan eksplorasi di daerah penangkapan pada jalur migrasi ikan seperti di Zone Ekonomi Eksklusif Indonesia (ZEEI). Jalur penangkapan di Indonesia terbagi menjadi 3 yaitu, Jalur I Jalur penangkapan ikan IA, meliputi perairan pantai sampai dengan 2 (dua) mil laut yang diukur dari permukaan air laut pada surut terendah. Jalur penangkapan ikan IB, meliputi perairan pantai di luar 2 (dua) mil laut sampai dengan 4 (empat) mil laut. Jalur Penangkapan Ikan II meliputi perairan di luar jalur penangkapan ikan I sampai dengan 12 (dua belas) mil laut diukur dari permukaan air laut pada surut terendah. Jalur Penangkapan Ikan III meliputi ZEEI dan perairan di luar jalur penangkapan ikan II (Peraturan Menteri Kelautan dan Perikanan No. 02/2011 pasal 4). Sedangkan untuk Wilayah Pengelolaan Perikanan dibagi berdasarkan kedalaman Perairan dangkal $(\leq 200 \mathrm{~m})$ dan perairan dalam $(\geq 200 \mathrm{~m})$. Ukuran kapal dan alat tangkap sangat menentukan wilayah penangkapan. Untuk kapal dengan ukuran lebih dari 60 GT beroperasi pada jalur penangkapan II dan III.

Salah satu kota di Jawa Tengah yang menjadi sentra kegiatan perikanan adalah Kota Pekalongan. Kota Pekalongan terletak di pesisir utara Provinsi Jawa Tengah dengan luas wilayah $45,25 \mathrm{~km}^{2}$ yang terdiri atas 4 (empat) kecamatan yaitu Pekalongan Utara, Pekalongan Selatan, Pekalongan Timur, dan Pekalongan Barat. Di Kota Pekalongan terdapat Pelabuhan Perikanan Tipe B yaitu PPN Pekalongan yang terletak di sebelah utara kota Pekalongan. Pelabuhan Perikanan Nusantara (PPN) Pekalongan merupakan salah satu "fishing base" dari armada penangkapan purse seine. Di Kota Pekalongan terdapat Pelabuhan Perikanan Tipe B yaitu PPN Pekalongan yang terletak di sebelah utara kota Pekalongan. Pelabuhan Perikanan Nusantara (PPN) Pekalongan merupakan salah satu "fishing base" dari armada penangkapan purse seine. Alat tangkap purse seine adalah alat tangkap dominan yaitu sebesar $84 \%$ dari total jumlah alat tangkap di PPN Pekalongan. Alat tangkap purse seine jumlahnya mengalami fluktuasi dari tahun 1998-2014. Pada tahun 1998 tercatat sebanyak 426 armada. Jumlah dalam kisaran 400 armada bertahan hingga tahun 2004. Dan terus menurun hingga menjadi 146 dan 149 armada pada tahun 2009 dan 2010. Tercatat jumlah kapal purse seine di PPN Pekalongan sebanyak 119 armada pada tahun 2012 dan turun menjadi 116 pada tahun 2013-2014. Secara ringkas 
jumlah armada penangkapan dengan alat tangkap Purse Seine di PPN Pekalongan dari tahun 1998 sampai 2014 mengalami penurunan. Persentase jumlah armada purse seine di PPN Pekalongan 2005 sampai 2014 dengan ratarata penurunan sebesar $11 \%$ per tahun (PPN Pekalongan, 2015). Jumlah alat tangkap purse seine ini menurun seiring dengan bertambahnya armada penangkapan mini purse seine di Pekalongan. Sehingga area penangkapan yang tadinya bisa sampai pada jalur III sekarang menjadi berpusat pada jalur II. Hal ini akan menimbulkan eksploitasi yang berlebih pada stok ikan pada jalur II. Penurunan ini menjadi salah satu ketertarikan peneliti untuk mengetahui bagaimana penggunaan faktor produksi secara teknis pada usaha penangkapan purse seine di Pekalongan. Pendugaan awal adalah penggunaan faktor produksi alat tangkap purse seine di Pekalongan belum efisien secara teknis. Adapun variabel input yang akan digunakan pada penelitian ini mengacu pada penelitian serupa yang dilakukan oleh del Hoyo, et.al (2004) yaitu lama trip (fishing days), GRT (Gross Registered Tonnage) kapal, jumlah ABK (crew members), sebagai faktor determinan yang pasti digunakan oleh penangkapan purse seine di lokasi penelitian.Tujuan dari penelitian ini adalah menghitung efiensi teknis usaha penangkapan purse seine di PPN Pekalongan secara stokastik dan deterministik dan menganalisis efisiensi teknis untuk mengetahui prospek keberlanjutan usaha penangkapan purse seine di PPN Pekalongan.

\section{METODE PENELITIAN}

\section{Rancangan Penelitian}

Penelitian ini merupakan penelitian survei dengan studi kasus usaha penangkapan purse seine di Pekalongan. Adapun yang menjadi fokus dalam penelitian ini adalah efisiensi dalam penggunaan input usaha secara teknis. Alokasi penggunaan input dari faktor-faktor produksi yang efektif dan efisien diharapkan akan dapat meningkatkan produksi perikanan tangkap. Secara umum, model fungsi produksi industri perikanan laut berbeda dari model fungsi produksi perusahaan biasa. Hal itu disebabkan karena jumlah hasil tangkapan tergantung pada tingkat upaya penangkapan dan besarnya populasi ikan. Besarnya populasi ikan itu sendiri dipengaruhi oleh tingkat upaya penangkapan. Kapal dengan sejumlah masukan hanya dapat secara langsung mengendalikan produksi upayanya, sedangkan besarnya hasil tangkapan sulit untuk dikendalikan secara langsung. Hal ini berbeda dari perusahaan biasa yang mampu secara langsung mengendalikan keluarannya (Anderson, 1975 dalam Sismadi, 2004). Pengertian efisiensi dalam produksi, bahwa efisiensi merupakan perbandingan output dan input berhubungan dengan tercapainya output maksimum dengan sejumlah input, artinya jika ratio output besar, maka efisiensi dikatakan semakin tinggi. Input usaha secara teknis dalam penangkapan dengan purse seine ini menggabungkan 3 (tiga) variabel utama (X) yang dianggap paling menentukan dalam teknis penangkapan. Fungsi dari penghitungan efisiensi teknis alat tangkap purse siene ini adalah menentukan gabungan penggunaan dari variabel input seperti apa yang dapat menghasilkan produksi penangkapan yang lebih efisien.

\section{Variabel yang diamati}

Variabel yang diamati pada penelitian ini adalah:

1. Nelayan adalah orang yang bekerja dalam kegiatan penangkapan perikanan dalam pengoperasian kapal penangkap ikan yaitu, nakhoda, juru mesin, ABK dan pemilik kapal. Dalam penelitian ini nelayan yang dijadikan responden adalah nakhoda dari masing-masing kapal Purse Seine.

2. Produksi atau output $(\mathrm{Y})$ adalah total volume ikan laut yang didaratkan kapal purse seine setiap tripnya dan satuan pengukuran yang digunakan adalah ton.

3. Lama trip adalah lamanya kegiatan penangkapan ikan dengan kapal purse seine selama kurun waktu 1 (satu) trip penangkapan. Dalam penelitian ini digunakan rata-rata lama hari melaut dalam 1 trip penangkapan selama musim puncak 3 tahun terakhir (2015 dan 2017).

4. GRT (Gross Registered Tonnage) adalah ukuran berat kapal yang tertera pada Surat Ijin Penangkapan Ikan (SIPI) dengan satuan Gross Ton (GT).

5. Tenaga Kerja. Tenaga kerja adalah jumlah orang atau tenaga yang digunakan dalam upaya penangkapan ikan per kapal selama satu trip penangkapan yang meliputi nakhoda, juru mesin, dan ABK, satuannya orang.

6. Efisiensi Teknis (TE) adalah perbandingan antara produksi aktual dengan tingkat produksi yang potensial dapat dicapai.

\section{Jenis Data Penelitian}

Data yang digunakan pada penelitian ini adalah data sekunder. Data sekunder yang dikumpulkan adalah lama trip penangkapan (fishing days), ukuran GRT ), dan jumlah ABK (number of crew members) kapal purse seine. Sedangkan untuk data produksi selama didapatkan dari laporan bulanan di PPN Pekalongan. Data sekunder tersebut terdiri dari data time series musim penangkapan pada tahun 2015 sampai 2017 serta data cross-section adalah data kapal purse seine di PPNP. Sehingga data tersebut dapat digabungkan menjadi data panel pada analisis data untuk mengetahui efisiensi teknis usaha penangkapan purse seine di PPN Pekalongan.

\section{Analisis Data}

Metode analisis menggunakan Stochastic Frontier Analysis (SFA) dan Deterministic Frontier Analysis (DFA). SFA dan DFA merupakan model parametrik yang digunakan untuk mengukur efisiensi teknis. Selain model parametrik ada pula model non parametrik yang bisa digunakan yaitu Data Envelopment Analysis (DEA). Alasan penggunaan metode ini adalah teknik SFA dan DFA ini memerlukan spesifikasi karakteristik teknologi pada suatu proses produksi. Sedangkan pada DEA tidak memerlukan 
hal tersebut (Kumbakhar dan Lovell, 2000). Metode penelitian ini menggunakan variabel teknis dari penangkapan purse seine untuk mengkaji apakah sudah tercapai penggunaan variabel tersebut secara efisisen (del Hoyo et.al, 2004) dengan data yang disesuaikan pada kondisi lapangan di Pekalongan. Metode diuraikan sebagai berikut:

\section{Fungsi penangkapan ikan}

Kemampuan maksimum untuk menangkap ikan dari suatu kapal ikan selama periode tertentu $\left(\mathrm{h}_{\mathrm{it}}\right)$ merupakan fungsi dari 2 input produksi, yaitu effort penangkapan $\left(\mathrm{E}_{\mathrm{it}}\right)$ dan stok yang dieksploitasi $\left(\mathrm{S}_{\mathrm{t}}\right)$ :

$$
h_{i t}=f\left(E_{i t} \cdot S_{t}\right)+\varepsilon_{i t}(1)
$$

Dimana $\varepsilon_{\text {it }}$ menunjukkan simbol untuk error. Sedangkan stok yang dieksploitasi menunjukkan interpretasi yang berbanding lurus (semakin banyak jumlah stok ikan akan menyebabkan tingginya jumlah hasil tangkapan), effort penangkapan lebih sulit untuk diinterpretasikan. Menurut Beverton dan Holt (1957) dalam del Hoyo et.al (2004) effort penangkapan digambarkan sebagai sebuah fungsi dari tenaga penangkapan (Wit) dan aktivitas tangkap (Tit), sehingga dituliskan sebagai berikut:

$$
\mathrm{E}_{\mathrm{it}}=\mathrm{g}\left(\mathrm{W}_{\mathrm{it}}, \mathrm{T}_{\mathrm{it}}\right) \text {. (2) }
$$

Aktivitas penangkapan ikan biasa diukur dengan lamanya kegiatan penangkapan (fishing days), sedangkan tenaga penangkapan adalah hasil dari kombinasi semua input faktor produktif (di sini adalah GRT dan jumlah ABK).

Untuk mengestimasi persamaan (2), data cross section, time series atau data panel dapat digunakan (Hanneson, 1983, Chambell, 1991). Untuk data cross section, kita harus memformulasikan beberapa hipotesis untuk distribusi dari stok ikan, karena variabel ini tidak mungkin diobservasi. Stok diasumsikan sama dengan jumlah semua kapal pada periode yang ditentukan (del Hoyo et.al., 2004). Pada data time series, informasi tentang perubahan jumlah stok harus tersedia atau setidaknya tersedia teknik statistik yang dapat digunakan untuk menghitungnya. Sedangkan data panel memperbolehkan estimasi jumlah stok sebagai "fixed effect" yang berbeda pada setiap periode tetapi sama untuk semua kapal pada periode tersebut. Masalah lain yang timbul adalah memilih fungsi yang tepat untuk mewakili effort penangkapan. Pilihan utama yang terbaik adalah bentuk fungsi fleksibel translog, karena ini mewakili aturan kedua perkiraan untuk segala kondisi pemilihan fungsi selama sesuai dengan teori yang dipilih (Berndt dan Christensen, 1973 dalam del Hoyo et.al., 2004). Bentuk fungsi translog adalah sebagai berikut:

$$
\begin{gathered}
\ln (\text { hit })=\alpha+\alpha_{1} \ln \left(\mathrm{FD}_{\mathrm{it}}\right)+\alpha_{2} \ln \left(\mathrm{GRT}_{\mathrm{it}}\right) \\
+\alpha_{3} \ln \left(\left(\mathrm{CM}_{\mathrm{it}}\right)+\frac{1}{2} \gamma_{11}\left\lceil\ln \left(\mathrm{FD}_{\mathrm{it}}\right)\right\rceil^{2}\right. \\
+\frac{1}{2} \gamma_{22}\left\lceil\ln \left(\mathrm{GRT}_{\mathrm{it}}\right)\right\rceil^{2}+ \\
\frac{1}{2} \gamma_{33}\left[\ln \left(\mathrm{CM}_{\mathrm{it}}\right)\right\rceil^{2}+\gamma_{12} \ln \left(\mathrm{FD}_{\mathrm{it}}\right) \ln \left(\mathrm{GRT}_{\mathrm{it}}\right)+
\end{gathered}
$$

$$
+\gamma_{13} \ln \left(\mathrm{FD}_{\mathrm{it}}\right) \ln \left(\mathrm{CM}_{\mathrm{it}}\right)+\gamma_{23} \ln \left(\mathrm{GRT}_{\mathrm{it}}\right) \ln \left(\mathrm{CM}_{\mathrm{it}}\right)
$$

Dimana (i) mewakili input dan (t ) mewakili waktu.

Pada persamaan (3), batasan simetris adalah paksaan secara teori untuk dapat mengidentifikasi nilai-nilai koefisien $\left(\gamma_{\mathrm{ij}}=\gamma_{\mathrm{ji}}\right)$. Tentunya, perbedaan batasan pada fungsi translog dapat diuji untuk mendapatkan bentuk final yang sesuai untuk fungsi penangkapan ikan (Garcia et.al. 2001 dalam del Hoyo et.al. 2004).

Deviasi ( $\varepsilon_{\text {it }}$ pada persamaan 1) berasal dari frontier penangkapan $\left[f\left(E_{i t} . S_{t}\right)\right]$ yang dipresentasikan di DFA sebagai asimetris error satu sisi dan pada SFA sebagai asimetris error dua sisi yang terbentuk dari dua sisi random $\left(v_{i t}\right)$ dan satu sisi error $\left(u_{i t} \geq 0\right)$ :

$$
\varepsilon i t=\text { it }- \text { uit }
$$

Jika data cross section digunakan, $\mathrm{t}$ dihilangkan dari persamaan (3). Sebaliknya, bila data panel yang digunakan maka $\mathrm{t}$ tetap dipakai di dalam persamaan. Pada DFA, frontier deterministik untuk data cross section bisa diestimasikan dengan Corrected Ordinary Least Square (COLS). Tahap pertama, regresi model klasik diestimasi dengan OLS (Ordinary Least Square). Tahap selanjutnya, intersep OLS dan residualnya dikoreksi dengan estimasi maksimum residual. Sebelumnya, semua kapal penangkapan akan berada di bawah garis frontier estimasi dan semua nilai residual yang baru (in-efisiensi teknis) adalah lebih kecil atau sama dengan nol (0) (Winsten, 1957 dalam del Hoyo et.al. 2004). Sehingga ketidakefisienan secara teknis dapat diestimasi, efisiensi teknis (Technical Efficiency atau TE) dapat dihitung dengan cara:

$$
\mathrm{Te}_{\mathrm{i}}=\mathrm{e}_{\mathrm{i}}^{\mathrm{u}}(5)
$$

Prosedur estimasi untuk stokastik frontier SFA tergantung pada jenis data yang digunakan. Data cross section dan data panel bisa diestimasi dengan metode Maximum Likelihood (ML). Saat menggunakan ML, estimasi akan diambil berdasarkan mean atau modus dari distribusi in-efisiensi untuk setiap DMU (JLMS; Jondrow et.al., 1982 dalam del Hoyo et.al. 2004). Sedangkan efisiensi teknis dapat dihitung dengan persamaan (5). Pilihan lain untuk nilai expected value dari hasil perhitungan persamaan (5) distribusi in-efisiensi juga bisa diestimasi dengan formula dari Battese dan Coelli (BC), 1998 (del Hoyo et.al. 2004).

Berdasarkan penelitian del Hoyo et.al. 2004 maka disini diajukan tiga macam model estimasi untuk efisiensi teknis, yaitu:

Model 1: DFA dengan data cross-section akan diestimasi dengan COLS.

Model 2: SFA dengan data cross-section akan diestimasi dengan ML, diasumsikan memiliki distribusi setengah normal untuk error term in-efisiensi. Estimasi error dengan proses JLMS and BC.

Model 3: SFA dengan data panel diestimasi dengan proses ML, diasumsikan memiliki distribusi setengah normal untuk error term in-efisiensi. Estimasi error dengan proses BC. 
HASIL

\section{Perikanan Purse Seine di Pelabuhan Perikanan Nusantara Pekalongan}

Sektor perikanan sangat berperan penting dalam peningkatan pendapatan daerah Kota Pekalongan. Ikan yang didaratkan di Pelabuhan Perikanan Nusantara Pekalongan sebagian besar adalah jenis ikan pelagis kecil, seperti ikan layang (Decapterus sp), layur (Trichiurus lepturus), ikan banyar (Rastrelliger kanagurta), ikan lemuru (Sardinella lemuru), cumi-cumi (Loligo sp), ikan bentong (Selar crumenophthalmus), ikan tongkol (Thunnus sp) dan lain-lain.

Produksi hasil tangkapan di Pelabuhan Perikanan Nusantara Pekalongan dalam lima tahun terakhir yaitu dari tahun 2011-2016 dapat dilihat pada Tabel 1.

Tabel 1. Produksi Hasil Tangkapan di PPN Pekalongan Tahun 2011-2015.

\begin{tabular}{cc}
\hline Tahun & Produksi Total (ton) \\
\hline 2011 & 18.831 \\
2012 & 19.579 \\
2013 & 17.751 \\
2014 & 20.791
\end{tabular}

\begin{tabular}{cc}
2015 & 17.598 \\
2016 & 19.358 \\
\hline Rata-rata & 18.985 \\
\hline
\end{tabular}

Sumber: Pelabuhan Perikanan Nusantara Pekalongan, 2017.

\section{Efisiensi Teknis Purse Seine}

Penelitian ini menganalis peranan input produksi dari kapal purse seine terhadap outputnya yaitu produksi penangkapan. Input produksi yang digunakan adalah $\mathrm{X}_{1}$ yaitu Lama Trip (hari), $X_{2}$ adalah GRT (Gross Registered Tonnage) kapal (GT), dan $X_{3}$ adalah jumlah Anak Buah Kapal (ABK) dengan satuan orang. Model yang digunakan untuk menilai efisiensi teknis ada 3 metode, yakni metode Deterministik Frontier Analisis (DFA) dengan menggunakan data cross section, Stotastik Frontier Analisis (SFA) dengan data cross section dan Stokastik Frontier Analisis (SFA) dengan menggunakan data panel. Adapun untuk kapal penangkap purse seine yaitu kapal dengan ukuran 60-90 GT. Untuk kapal purse seine kelompok 60-90 GT diambil 18 kapal. Adapun hasil output pengolahan data dengan menggunakan metode DFA dan SFA adalah sebagai berikut:

Output model 1 Deterministik Frontier Analisis untuk kapal purse seine 60-90 GT

Tabel 2. Ouput Metode DFA untuk kapal purse seine

\begin{tabular}{ccccc}
\hline & Coefficients & Standard Error & t Stat & P-value \\
\hline Intercept & $-0,142250353$ & 13,1016693 & $-0,01086$ & 0,99149 \\
X1(Lama Trip) & $-0,274560594$ & 0,68158125 & $-0,40283$ & 0,693158 \\
X2 (GRT) & 0,678278848 & 2,32597524 & 0,291611 & 0,774861 \\
X3(ABK) & 2,57836398 & 1,7830701 & 1,446025 & 0,170184 \\
\hline
\end{tabular}

Sumber: Data Sekunder yang diolah, 2017

\section{Output model 2 Stokastik Frontier Analisis untuk kapal purse seine 60-90 GT}

Tabel 3. Output Metode SFA untuk kapal purse seine

\begin{tabular}{ccccc}
\hline & Coefficients & Standard Error & t Stat & P-value \\
\hline Intercept & $-2,430121219$ & 13,10167 & $-0,18548$ & 0,855512 \\
X1(Lama Trip) & $-0,274560594$ & 0,681581 & $-0,40283$ & 0,693158 \\
X2 (GRT) & 0,678278848 & 2,325975 & 0,291611 & 0,774861 \\
X3(ABK) & 2,57836398 & 1,78307 & 1,446025 & 0,170184 \\
\hline
\end{tabular}

Sumber: Data Sekunder yang diolah, 2017 
Output model 2 Stokastik Frontier Analisis untuk kapal purse seine 60-90 GT

Tabel 4. Output Metode SFA untuk kapal purse seine 60-90 GT

\begin{tabular}{ccccc}
\hline Variable & Coefficient & Std. Error & t-Statistic & Prob. \\
\hline X1(Lama Trip) & 0.192065 & 0.294540 & 0.652083 & 0.5173 \\
X2 (GRT) & 1.476 .541 & 0.961043 & 1.536 .395 & 0.1307 \\
X3(ABK) & 1.146 .675 & 0.731659 & 1.567 .225 & 0.1234 \\
$\mathrm{C}$ & -0.583093 & 5.030 .707 & -0.115907 & 0.9082 \\
$\lambda^{\wedge} 2$ & 0.077725238 & & & \\
$\Sigma \mathrm{u}$ & 0.0711 & & & \\
$\Sigma \mathrm{v}$ & 0.2550 & & &
\end{tabular}

Sumber: Data Sekunder yang diolah, 2017

\section{PEMBAHASAN}

Armada penangkapan purse seine di PPN Pekalongan yang memiliki GRT 60-90 GT produksi rata-rata per trip 54,4 ton per trip dengan lama trip antara 30 hingga 86 hari. Jumlah ABK yang membantu kegiatan operasi penangkapan sebanyak 30-40 orang per trip. Ukuran panjang (L) $21,9 \mathrm{~m}$ hingga 24,5 m; lebar (B) 6,65 - 6,69 m; dan dalam (D) 1,72,3 m. Kekuatan mesin kapal antara 250-350 pk, perbekalan solar yang dibawa berkisar 16.000 hingga 32.000 liter solar per trip. Sedangkan untuk penyimpanan ikan hasil tangkapan sudah menggunakan sistem refrigerasi dari air laut (Refrigrated Sea Water atau RSW). Sehingga hasil tangkapan tersimpan dalam kondisi beku. Penangkapan juga menggunakan alat bantu berupa lampu dan rumpon yang sifatnya tidak menetap.

\section{Output model 1 Deterministik Frontier Analisis untuk kapal purse seine 60-90 GT menggunakan data cross section}

Berdasarkan hasil pengolahan data cross section pada kelompok kapal purse seine berukuran 60-90 GT dengan metode DFA didapatkan hasil bahwa secara simultan faktor produksi input berupa lama trip, GRT, dan jumlah ABK tidak memiliki pengaruh terhadap hasil tangkapan. Ini ditunjukkan dengan nilai sig. Uji F sebesar 0,49. Dan uji parsial (uji t) untuk masing-msaing variabel juga menunjukkan hasil yang sama bahwa secara parsial masingmasing variabel baik $\mathrm{X}_{1}, \mathrm{X}_{2}$ maupun $\mathrm{X}_{3}$ belum memberikan pengaruh yang besar terhadap output usaha penangkapan. Nilai koefisien korelasi $(\mathrm{R}=0,39)$ menunjukkan efisiensi yang rendah pada penggunaan faktor produksi. Bentuk model persamaan yang terbentuk dari metode DFA adalah:

$$
\mathrm{Ln} \mathrm{Y}=0,541-0,273 \ln \mathrm{X} 1+0,678 \ln \mathrm{X} 2+2,578 \ln \mathrm{X} 3
$$

Dimana:

$\mathrm{Y}=\operatorname{produksi}(\mathrm{kg})$

$\mathrm{X} 1$ = lama trip (hari)

$\mathrm{X} 2=\mathrm{GRT}$ (ton)

$\mathrm{X} 3$ = jumlah ABK (orang)
Berdasarkan hasil pengujian dapat diketahui bahwa variabel $X_{1}$ (lama trip) memiliki hubungan negatif dengan variabel Y (produksi). Ini dapat dijelaskan dengan daerah penangkapan kelompok purse seine dibawah 90 GT masih terbatas di area WPP 712 (Laut Jawa) yang tingkat pemanfaatan sumberdaya ikan pelagis kecil sudah cukup besar yaitu $0,59(59 \%)$. Tingkat pemanfaatan dijelaskan dalam Kepmen Kelautan dan Perikanan No. 47 tahun 2016 tentang Estimasi Potensi, Jumlah Tangkapan Yang Diperbolehkan, Tingkat Pemanfaatan Sumberdaya Ikan Di Wilayah Pengelolaan Perikanan Negara Republik Indonesia.

\section{Output model 2 Stokastik Frontier Analisis untuk kapal} purse seine 60-90 GT menggunakan data cross section

Pengujian variabel input terhadap variabel output pada kapal penangkap purse seine dengan model kedua yaitu Stokastik Frontier Analisis (SFA) memberikan hasil yang hampir serupa dengan pengujian model DFA. Hasil perhitungan koefisien korelasi $(0,39)$ dan sig. F $(0,49)$ untuk kapal purse seine memiliki nilai yang sama dengan model DFA. Secara bersama-sama masing-masing variabel kurang memberikan dampak terhadap produksi hasil tangkapan. Dan penggunaan variabel input masih belum efisien. Nilai koefisien untuk masing-masing variabel input $\left(\mathrm{X}_{1}, \mathrm{X}_{2}\right.$, dan $\mathrm{X}_{3}$ ) sama dan hanya nilai intersep saja yang berbeda. Hasil model persamaan yang terbentuk pada kelompok kapal purse seine ukuran 60-90 GT adalah:

$$
\text { Ln } \mathrm{Y}=-0,243-0,273 \ln \mathrm{X} 1+0,678 \ln \mathrm{X} 2+2,578 \ln \mathrm{X} 3
$$

Dimana:

$\mathrm{Y}=$ produksi $(\mathrm{kg})$

$\mathrm{X} 1$ = lama trip (hari)

$\mathrm{X} 2=\mathrm{GRT}$ (ton)

$\mathrm{X} 3$ = jumlah ABK (orang)

Pengujian secara parsial untuk masing-masing variabel dalam metode SFA untuk kelompok ini menghasilkan kurangnya peran dari tiap variabel input (lama trip, GRT, dan jumlah ABK) untuk menghasilkan perubahan output penangkapan yang besar. Seperti halnya pada pengujian dengan metode DFA variabel $\mathrm{X}_{1}$ (lama trip) 
justru memiliki sifat negatif (mengurangi) terhadap produksi penangkapan purse seine.

\section{Output model 3 Stokastik Frontier Analisis Untuk kapal purse seine 60-90 GT menggunakan data panel tahun 2015-2017}

Pengujian pengaruh variabel input terhadap output untuk model yang ketiga adalah menggabungkan data time series dan cross section atau data panel. Tujuannya adalah untuk melihat secara bersama produksi dari tiap entitas sampel selama kurun waktu tertentu yang dihasilkan dari penggunaan ketiga faktor input yang telah dibahas pada metode sebelumnya. Pada metode SFA menggunakan data panel dilakukan uji secara simultan dan parsial. Dan nilai efisiensi teknis dari penggunaan variabel input dapat diketahui. Pengujian dengan metode SFA data panel didapatkan hasil nilai uji $\mathrm{F}$ (Anova) 1,79 dan sig. P-value sebesar 0,16 pada kapal purse seine ukuran 60-90 GT. Hal ini memiliki makna bahwa model yang diprediksi dengan metode SFA data panel untuk kapal 60-90 GT kurang berperan secara signifikan. Model persamaan yang terbentuk dari metode SFA data panel untuk kelompok kapal 60-90 GT adalah:

$$
\mathrm{Ln} \mathrm{Y}=-0,583+0,192 \ln \mathrm{X} 1+1,476 \ln \mathrm{X} 2+1,146 \ln \mathrm{X} 3
$$

Dimana :

$\mathrm{Y}=$ produksi $(\mathrm{kg})$

$\mathrm{X} 1$ = lama trip (hari)

$\mathrm{X} 2=\mathrm{GRT}$ (ton)

$\mathrm{X} 3$ = jumlah $\mathrm{ABK}$ (orang)

Variabel lama trip, GRT dan jumlah ABK pada kapal purse seine 60-90 GT ternyata tidak berpengaruh secara signifikan terhadap produksi penangkapan. Hal ini dibuktikan dengan nilai P-value dari ketiga variabel bebas tersebut yang lebih besar dari taraf signifikansi 0,05 hingga 0,10 . Sehingga saat ada penambahan dari ketiga faktor input produksi tersebut kemungkinan besar tidak mampu meningkatkan produksi penangkapan ikan. Efisiensi teknis dilihat dari nilai korelasi sebesar 0,311 yang berarti masih kurang efisien karena nilainya masih dibawah 1.

Berdasarkan hasil pengamatan dari estimasi efisiensi teknis armada penangkapan purse seine ukuran 60-90 GT memberikan gambaran bahwa faktor input yang digunakan untuk mendukung produksi penangkapan tidak efisien. Sehingga keberlanjutan usaha penangkapan purse seine ukuran kapal 60-90 GT sudah cukup rawan jika akan dikembangkan. Perubahan area yang lebih jauh dari WPP 712 (Laut Jawa) mungkin patut dipertimbangkan. Selain itu juga perlu menambah ketrampilan ABK agar bisa lebih efisien dalam penggunaannya untuk kegiatan penangkapan.

\section{KESIMPULAN}

Hasil simpulan yang dapat diambil dari penelitian ini adalah efisiensi teknis dari kapal purse seine ukuran 6090 GT menunjukkan nilai inefisiensi dalam penggunaan ketiga variabel input (lama trip, GRT, jumlah ABK) dengan nilai 0,311 . Hal ini diperkuat dengan hasil nilai korelasi (R) pada metode Deterministik Frontier dan Stokastik Frontier dengan data cross section yang rendah $(0,39)$. Pada armada penangkapan purse seine ukuran 60-90 GT, ketiga variabel input tidak mempunyai pengaruh yang signifikan terhadap perubahan jumlah produksi penangkapan. Hal ini bisa disebabkan oleh jumlah stok ikan target penangkapan yang semakin menurun dan daerah penangkapan yang masih berada di sekitar Laut Jawa (WPP 712). Untuk metode Stokastik dengan menggunakan data panel hasil pengujian untuk kelompok kapal dengan ukuran 60-90 GT menunjukkan bahwa ketiga variabel tidak berpengaruh cukup besar dalam perubahan jumlah produksi penangkapan. Ini akan memberikan efek negatif terhadap keberlanjutan usaha penangkapan purse seine di Pelabuhan Perikanan Nusantara Pekalongan.

\section{UCAPAN TERIMA KASIH}

Penulis mengucapkan terima kasih kepada Fakultas Perikanan dan Ilmu Kelautan Universitas Diponegoro yang telah memberikan bantuan Biaya Penelitian dengan Dana Anggaran PNBP Undip Tahun Anggaran 2017 berdasarkan Surat Perjanjian Pelaksanaan Penelitian FPIK, Undip No. 2291/UN7.3.10/LT/2017. Sehingga penelitian ini dapat dilaksanakan dengan baik. Kepada tim penelitian Himma Galuh N, I. Firdaus, Andika Wiratama, M. F. Hafidz, serta pihak pengelola Pelabuhan Perikanan Nusantara Pekalongan, dan nelayan Purse Seine Pelabuhan Perikanan Nusantara Pekalongan, penulis mengucapkan terima kasih untuk segala bantuannya.

\section{DAFTAR PUSTAKA}

Campbell, H. F. 1991. Estimating the Elasticity of Substitution between Restricted and Unrestricted Inputs in A Regulated Fishery: A Probit Approach. Journal of Environmental Economics and Management, 20: 262-274.

del Hoyo, J. J. G., D.C. Espino, and R.J. Toribio. 2004. Determination of Technical Efficiency of Fisheries by Stochastic Frontier Models: a Case on the Gulf of Ca'diz (Spain). Journal of Marine Science, 61: 416e421. doi:10.1016/j.icesjms.2004.02.003

Hannesson, R. 1983. Bioeconomic Production Function In Fisheries: Theoretical And Empirical Analysis. Canadian Journal of Fisheries and Aquatic Sciences, 40: 968-982.

Keputusan Menteri Kelautan dan Perikanan No. 47 tahun 2016 tentang Estimasi Potensi, Jumlah Tangkapan Yang Diperbolehkan, Tingkat Pemanfaatan Sumberdaya Ikan Di Wilayah Pengelolaan Perikanan negara Republik Indonesia

Kumbhakar, S. C., and C. A. K Lovell,. 2000. Stochastic Frontier Analysis. Cambridge University Press, Cambridge.

Pelabuhan Perikanan Nusantara Pekalongan. 2014. Jumlah Kapal Perikanan Menurut Jenis Alat Tangkap di Pelabuhan Perikanan Nusantara Pekalongan. PPN Pekalongan. 
2015. Data

Produksi Harian di Pelabuhan Perikanan Nusantara Pekalongan. PPN Pekalongan.

2016. Data

Produksi Harian di Pelabuhan Perikanan Nusantara Pekalongan. PPN Pekalongan. 2017. Data

Produksi Harian di Pelabuhan Perikanan Nusantara Pekalongan. PPN Pekalongan.
Peraturan Menteri Kelautan dan Perikanan No. 02/2011 tentang Jalur-jalur Penangkapan Ikan

Sismadi. 2006. Analisis Efisiensi Penggunaan Input Alat Tangkap Purse Seine di Kota Pekalongan (Thesis). Magister Ilmu Ekonomi dan Studi Pembangunan, Universitas Diponegoro, Semarang. 